\title{
EFFECT OF SELECTION AND DURATION OF STORAGE OF BROILER HATCHING EGGS ON HATCHABILITY PERCENT AND CHICK WEIGHT
}

\author{
T. M. Mousa-Balabel and El. Kh. Y. Saleem* \\ Hygiene and Preventive Medicine Dept.,' Fac. of Vet. Med., Tanta University. \\ ${ }^{*}$ Hygiene and Animal Husbandry Dept., Fac. of Vet. Med., Zagazig University, Egypt.
}

\begin{abstract}
This work was carried out on a number of 800 broiler breeder fertile eggs from a commercial broiler strain (Lohmann) which reared on a deep litter system at Menoufia Governorate, Egypt. This experiment was begun in September 1, 2003. All selectable eggs were divided into 20 groups (40 each). The first nine groups were stored for different periods $(0,3,6,9,12,15,18,21$ and 24 days). The groups from 10 to 13 were stored for 6 days and differ only in the number of egg turning during the storage (0, 3, 6 and 12 times / day) period. The groups 14, 15 and 16 were selected on the basis of egg weight (35 to 45, 46 to 55 and 56 to $65 \mathrm{~g})$. While, the groups from 17 to 20 were selected from different flock ages 34, 44,54 and 64weeks. This work was conducted to study the effect of flock age, egg weight, duration of egg storage and number of egg turning during pre-incubation storage on fertility, hatchability, incubation period, post-hatching chick weight and chick weight at 7 days old in addition, egg weight loss during different storage periods.
\end{abstract}

Egg weight loss increased with each three days increasing in the storage period. The incubation period,post-hatching weight and chick weight after 7 days old were increased by increasing the flock age and egg weight while, the fertility percent and hatchability of fertile eggs were decreased. Also, the fertility percent, hatchability of fertile eggs, post- hatching weight and chick weight after 7 days old were decreased by increasing the duration of storage but, the incubation period was increased.Increasing the number of eggs 
turning during pre-incubation storage led to decrease in the hatching time and increase in the fertility percent, hatchability of fertile eggs, post- hatching weight and chick weight after 7 days old.

From this work, we conclude that, the hatchability of fertile eggs and chicks weight can be improved by good selection of broiler hatching eggs on the bases of; flock age ranging from 34 to 44 weeks, their eggs weight ranging from 46 to $55 \mathrm{~g}$, pre-incubation storage not more than 9 days and egg turning during pre-incubation storage not less than three times daily.

\section{INTRODUCTION}

When a problem occurs in hatchability, usually it can be categorized as a breeder flock, egg handling or hatchery problem. Hatching eggs are not incubated immediately after laying for a variety of reasons. The most obvious reason is that eggs are not incubated on the farms on which they are produced. Transport of eggs from breeder farms to commercial hatcheries means that eggs must be stored on farm,as daily delivery of hatching eggs is not practical. Eggs may also be stored at the hatchery for several reasons. In times when hatching eggs are plentiful, incubator space may be limited therefore requiring storage of the surplus eggs. Storage of eggs may also occur if the hatchery has a reduction in the number of chicks required for placement on grow-out farms.

The hatchability of fertile eggs declined with long storage period and the most obvious effect observed in eggs stored for 14 days (Elibol et al.,2002). The storage duration of 18 days resulted in longer incubation period with depressed chicks relative growth (Tona et al., 2003). The $\mathrm{pH}$ of albumen was higher in eggs stored for 8 days than in fresh eggs(Lapao et al., 1999) and carbon dioxide concentration was greater in air cell of eggs stored for three days compared to those stored for 18 days while, the oxygen concentration was greater in eggs stored for 18 days (Tona et al., 2003). Additionally, the chick quality and livability were reduced by long storage of eggs as;some chicks may be processed while still wet and others may get dehydrated from trying to pull chicks at the right time(Meijerhof, 1995).

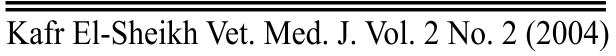


The hatchability of fertile eggs decreased and early embryonic mortality increased by increasing the flock age(Vick et al.,1993 and Ipek and Sahan,2001).Also,the eggs from an older(52 and 53 weeks of age)broiler breeder flock had a lower fertility than that from a younger (30 and 31 weeks of age) flock ( Elibol et al., 2002 ).

Medium sized eggs $(50-60 \mathrm{~g})$ had higher fertility $(85 \%)$, better hatchability $(81.82 \%)$ and lower late embryonic mortality $(18.82 \%)$ than either too small (less than 50g) or too large (more than 60g) sized eggs (Mohed et al., 2000) and the egg weight had a significant effect on posthatching weight as; the largest weight of hatched chicks $(44.25 \mathrm{~g})$ was obtained from the largest egg weight $(60 \mathrm{~g})$ (Veterany et al., 2001). In addition, the highest hatchability was recorded for $60 \mathrm{~g}$ egg weight (Veterany and Jedlicka, 2001). Moreover, the embryonic mortality was found to be higher in small weighted eggs and was the highest during the early stages of development which ranged from 0 to 7 days of incubation (Bhutia et al., 2002) and the average live chicks weight up to one week was higher for large eggs weight (Kang et al., 2002). The optimum egg weight for hatchability was in the range of 45-50 g for chicken (Kumar et al., 2002). As well as, the hatchability of fertile eggs was increased by turning them 4 or 24 times per day during storage period (Elibol et al., 2002).

The object of this work is to determine the effect of storage period, turning times during storage, eggs weight and flock age on the fertility, hatchability, incubation period, post- hatching chick weight and chick weight at 7 days old in addition, egg weight loss during different storage periods.

\section{MATERIALS AND METHODS}

A number of 800 broiler breeder fertile eggs were selected from a commercial broiler strain(Lohmann), which reared on a deep litter system at Menoufia Governorate,Egypt.All eggs were divided into 20 groups (40 each).The eggs in the groups from 1 to 9 were stored for different storage 
periods as followed; $0,3,6,9,12,15,18,21$, and 24 days.Also,these eggs were weighed immediately before and after storage to determine the egg weight loss during storage as well as, to study the effect of duration of storage on some hatching traits. The eggs were stored at $10{ }^{\circ} \mathrm{Cwith}$ a relative humidity $75 \%$ and turned 6 times / day according to Ruiz et al. (2002). After the end of storage all eggs were kept in room temperature ( 25 C) for 12 hours before setting in the incubator to avoid the shock of warming the eggs too rapidly according to Kang et al.(2002). The eggs in the groups from 10 to 13 were stored for 6 days only under the same previous condi-tions but differ only in the number of egg turning during the storage period as followed;0,3,6 and 12 times/day to explore the effect of the number of eggs turning during pre-incubation storage on some hatching parameters.

The eggs in the groups 14,15and 16were selected to be differed only in the eggs weight where, the egg weight in the $14^{\text {th }}$ group ranged from 35 to $45 \mathrm{~g}, 46$ to $55 \mathrm{~g}$ for the $15^{\text {th }}$ group and 56 to $65 \mathrm{~g}$ for the $16^{\text {th }}$ group to investigate the effect of eggs weight on some hatching parameters. All previous eggs (1 to 16 groups) were selected from breeder flock at the peak age of production (36 weeks) while, the eggs in the last four groups (17 to 20 groups) were selected from different breeder flock ages $(34,44$, 54and 64weeks) to study the effect of breeder flock age on hatching eggs and some hatching parameters. All investigated eggs were incubated in automatic incubator at temperature of 37 to $37.5 \circ \mathrm{C}$ for the first $18^{\text {th }}$ days with a relative humidity $55-60 \%$ while, during the last three days the temperature of hatching are $36.5-37$ C with a relative humidity $75 \%$ according to Altan et al. (2002). All incubated eggs were turned automatically 9 times / day during the first 16 days of the incubation only. All investigated eggs were held during storage and incubation with large end of the eggs being up.

\section{Measurements:}

1- Egg weight loss during storage =Fresh egg weight - Egg weight at the end of storage period. 
2- Incubation period = Time elapsed from setting the eggs in the incubator till hatching of the last egg in the group.

3- Fertility $\%=$ Number of fertile eggs / Number of all eggs set.

4- The fertility was determined by candling the eggs after 7 days from incubation.

5- Hatchability percent of fertile eggs $=$ Number of hatching chicks / Number of all fertile eggs set.

6- Post - hatching chick weight was recorded.

7- Chick weight at 7 days was recorded by rearing them in the farm on a deep litter system and fed on a starter ration $(21 \%$ protein, Cairo Company).

\section{Results were recorded in tables (1 to 4$)$.}

Statistical analysis:

Data were collected, arranged, summarized and analyzed using the general linear model procedures of the SAS, Institute INC (1985).

\section{RESULTS AND DISCUSSION}

Fresh egg weight did not differ between any of the nine groups. Egg weight loss increased with each three days increasing in the storage period (table 1). Nearly all weight loss is due to the diffusive transport of water vapor across the eggshell. A species-specific water vapour conductance, number of eggshell pores, pore structure and thickness of eggshell determine the rate of water loss. Differing the level of relative humidity in the store and / or the incubator can control the rate of weight loss from lay to pip.If the egg loses its weight quickly,raising the humidity will slow the rate of evaporation through the egg's pores and conversely lowering the humidity will increase the rate of weight loss.

Egg storage did not significantly reduce the percent of fertility and hatchability when eggs were stored for a maximum of six days.However, after nine days of storage, there was a significant decrease in the hatchability of fertile eggs. The lowest percentage of hatchability (10\%) was obtained when the eggs were stored for 24 days as shown in table(1).Hatchability losses may be attributed to excessive egg storage often can be acco$\overline{\text { Kafr El-Sheikh Vet. Med. J. Vol. } 2 \text { No. } 2 \text { (2004) }}$ 
mpanied by an increase in the percentage of early and late embryonic mortality (Elibol et al., 2002) and this mortality was recorded in the first two or three days of incubation and distinguished by the presence of slight blood around the germinal disc.

Chick weight at placement(post-hatching weight)was also positively affected as; chicks weight from eggs stored for 9 days or longer significantly weighs less than chicks weight from eggs stored for 6 days or less (table 1).This may be attributed to egg weight loss by long storage period and subsequently the small egg weight gives small chick compared to larger one.

There was no significant difference in the incubation period for eggs stored for 12 days or less. But, the incubation period inecreased by increasing the storage period (more than 12 days). Egg storage significantly affected the chick weight at 7 days old as; the chick weight was smaller in the groups that stored for 9 days or more as shown in table (1). This could have been a result of decrease in egg weight by long storage, also resulting in a small chick hatch weight and finally broiler body weights were influenced (Tona et al., 2003).

The number of eggs turning during storage had no effect on hatching time while, if the number of turning increased, it led to increasing the hatchability of fertile eggs, post-hatching chick weight and chick weight at 7 days old (table 2). This may be a result of the turning of egg which reduces the late embryonic mortality and prevents the embryo from sticking to shell membrane that reduces the hatchability percent (Elibol and Brake, 2003).

Eggs from different flock ages showed a significant difference in the incubation period, hatchability of fertile eggs, post-hatching chick weight and chick weight at 7 days old as, the incubation period, post-hatching chick weight and chick weight at 7 days old were increased by increasing the flock ages while, the hatchability of fertile eggs was decreased by increasing the flock ages as shown in table (3). This may be attributed to the egg weight and shell porosity at the beginning of lay were low but generally by the $5^{\text {th }}$ week of lay both characters increased (Tullett and Smith, 1983) and early embryonic mortality was increased by increasing Kafr El-Sheikh Vet. Med. J. Vol. 2 No. 2 (2004) 
the flock age as a result of larger eggs from old flock age resulting in increasing the amount of water loss from the egg (Vick et al., 1993).

There was a relationship between egg weight and some hatching parameters as; the incubation period,post-hatching chick weight and chick weight at 7 days old were increased by increasing the egg weight. While, increasing the egg weight decreased the hatchability of fertile eggs(table 4). This may be explained as the increasing in egg weight is mostly accompanied by decreasing in eggshell quality (thinner and very porous).

From this work, we conclude that, the hatchability of fertile eggs and chicks weight can be improved by good selection of broiler hatching eggs on the basis of; flock age ranging from34 to 44 weeks, their eggs weight ranging from 46 to $55 \mathrm{~g}$, pre-incubation storage not more than 9 days and egg turning during pre-incubation storage not less than three times daily.

Table (1): Effect of egg storage period on some hatching parameters.

\begin{tabular}{|c|c|c|c|c|c|c|c|c|}
\hline Variables & 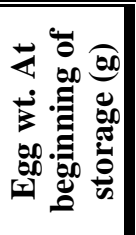 & 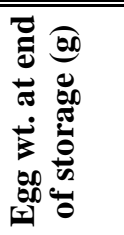 & 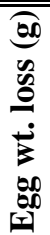 & 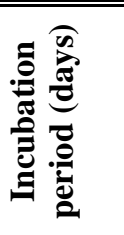 & 总 & 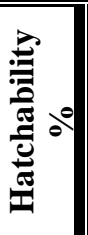 & 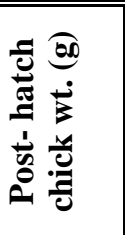 & 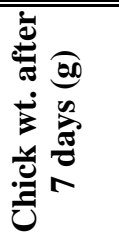 \\
\hline No storage & $\begin{array}{c}45 \pm \\
0.018 \mathrm{a}\end{array}$ & $\begin{array}{c}45 \pm \\
0.018 \mathrm{a}\end{array}$ & 0 & $\begin{array}{c}20.5 \pm \\
0.036 \mathrm{a}\end{array}$ & 100 & 89 & $\begin{array}{c}41 \pm \\
0.011 \mathrm{a}\end{array}$ & $\begin{array}{c}125 \pm \\
0.019 \mathrm{a}\end{array}$ \\
\hline 3 days storage & $\begin{array}{c}45 \pm \\
0.032 \mathrm{a}\end{array}$ & $\begin{array}{c}44 \pm \\
0.022 \mathrm{~b}\end{array}$ & 1 & $\begin{array}{c}20.3 \pm \\
0.011 \mathrm{a} \\
\end{array}$ & 100 & 89 & $\begin{array}{c}40 \pm \\
0.062 \mathrm{~b}\end{array}$ & $\begin{array}{c}124 \pm \\
0.052 \mathrm{~b}\end{array}$ \\
\hline 6 days storage & $\begin{array}{c}45 \pm \\
0.026 \mathrm{a} \\
\end{array}$ & $\begin{array}{c}43 \pm \\
0.016 \mathrm{c} \\
\end{array}$ & 2 & $\begin{array}{c}20.5 \pm \\
0.023 \mathrm{a} \\
\end{array}$ & 98 & 88 & $\begin{array}{c}41 \pm \\
0.016 \mathrm{a} \\
\end{array}$ & $\begin{array}{c}124 \pm \\
0.031 \mathrm{~b} \\
\end{array}$ \\
\hline 9 days storage & $\begin{array}{c}45 \pm \\
0.009 \mathrm{a} \\
\end{array}$ & $\begin{array}{c}40 \pm \\
0.026 \mathrm{~d} \\
\end{array}$ & 5 & $\begin{array}{c}20.1 \pm \\
0.049 \mathrm{a} \\
\end{array}$ & 90 & 84 & $\begin{array}{c}38 \pm \\
0.031 \mathrm{c} \\
\end{array}$ & $\begin{array}{c}105 \pm \\
0.027 \mathrm{c}\end{array}$ \\
\hline 12 days storage & $\begin{array}{c}45 \pm \\
0.041 \mathrm{a}\end{array}$ & $\begin{array}{c}40 \pm \\
0.015 \mathrm{~d}\end{array}$ & 5 & $\begin{array}{c}20.1 \pm \\
0.007 \mathrm{a}\end{array}$ & 85 & 75 & $\begin{array}{c}33 \pm \\
0.036 \mathrm{~d}\end{array}$ & $\begin{array}{c}101 \pm \\
0.008 \mathrm{~d}\end{array}$ \\
\hline 15 days storage & $\begin{array}{c}45 \pm \\
0.028 \mathrm{a} \\
\end{array}$ & $\begin{array}{c}38 \pm \\
0.019 \mathrm{e} \\
\end{array}$ & 7 & $\begin{array}{c}21 \pm \\
0.031 \mathrm{~b}\end{array}$ & 75 & 68 & $\begin{array}{c}33 \pm \\
0.022 \mathrm{~d} \\
\end{array}$ & $\begin{array}{c}98 \pm \\
0.013 \mathrm{f}\end{array}$ \\
\hline 18 days storage & $\begin{array}{c}45 \pm \\
0.013 \mathrm{a} \\
\end{array}$ & $\begin{array}{c}35 \pm \\
0.008 \mathrm{f}\end{array}$ & 10 & $\begin{array}{c}21.1 \pm \\
0.030 \mathrm{~b}\end{array}$ & 70 & 50 & $\begin{array}{c}30 \pm \\
0.009 \mathrm{e}\end{array}$ & $\begin{array}{c}95 \pm \\
0.019 \mathrm{~g}\end{array}$ \\
\hline 21 days storage & $\begin{array}{c}45 \pm \\
0.019 \mathrm{a} \\
\end{array}$ & $\begin{array}{c}32 \pm \\
0.014 \mathrm{~g} \\
\end{array}$ & 13 & $\begin{array}{c}21.5 \pm \\
0.018 \mathrm{c}\end{array}$ & 60 & 30 & $\begin{array}{c}28 \pm \\
0.018 \mathrm{f}\end{array}$ & $\begin{array}{c}68 \pm \\
0.042 \mathrm{~h} \\
\end{array}$ \\
\hline 24 days storage & $\begin{array}{c}45 \pm \\
0.022 \mathrm{a}\end{array}$ & $\begin{array}{c}30 \pm \\
0.031 \mathrm{~h}\end{array}$ & 15 & $\begin{array}{c}22 \pm \\
0.011 \mathrm{~d}\end{array}$ & 30 & 10 & $\begin{array}{c}25 \pm \\
0.028 \mathrm{~g}\end{array}$ & $\begin{array}{c}68 \pm \\
0.030 \mathrm{~h}\end{array}$ \\
\hline
\end{tabular}

Kafr El-Sheikh Vet. Med. J. Vol. 2 No. 2 (2004) 
Mean \pm Standard Error.

* Means which subscript with different small litters(a,b,c...)differ significantly at $(\mathrm{P}<0.05)$.

Table (2): Effect of number of egg turning during storage on some hatching parameters.

\begin{tabular}{|c|c|c|c|c|c|}
\hline Variables & 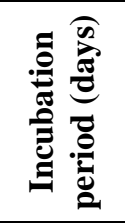 & 告 & 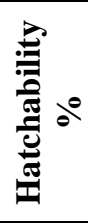 & 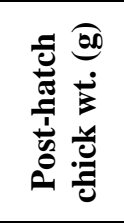 & 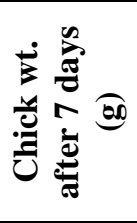 \\
\hline No turning & $\begin{array}{l}21.7 \pm \\
0.016 \mathrm{a}\end{array}$ & 70 & 40 & $\begin{array}{c}38 \pm \\
0.018 \mathrm{a}\end{array}$ & $\begin{array}{c}105 \pm \\
0.024 \mathrm{a}\end{array}$ \\
\hline 3 times turning & $\begin{array}{l}20.3 \pm \\
0.031 \mathrm{~b}\end{array}$ & 80 & 85 & $\begin{array}{c}42 \pm \\
0.009 \mathrm{~b}\end{array}$ & $\begin{array}{c}125 \pm \\
0.013 \mathrm{~b}\end{array}$ \\
\hline 6 times turning & $\begin{array}{l}20.5 \pm \\
0.029 c\end{array}$ & 85 & 88 & $\begin{array}{c}41 \pm \\
0.032 \mathrm{c}\end{array}$ & $\begin{array}{c}128 \pm \\
0.011 \mathrm{c}\end{array}$ \\
\hline 12 times turning & $\begin{array}{c}20.1 \pm \\
0.028 \mathrm{~d}\end{array}$ & 90 & 91 & $\begin{array}{c}43 \pm \\
0.019 \mathrm{~d}\end{array}$ & $\begin{array}{c}126 \pm \\
0.039 \mathrm{~d}\end{array}$ \\
\hline
\end{tabular}

Mean \pm Standard Error.

* Means which subscript with different small litters(a,b,c...)differ significantly at $(\mathrm{P}<0.05)$.

Table (3): Effect of eggs from different flock ages on some hatching parameters.

\begin{tabular}{|c|c|c|c|c|c|}
\hline Flock age & 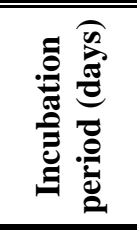 & 赵 & 营 & 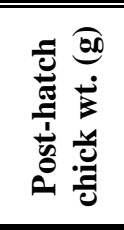 & 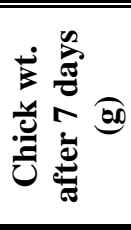 \\
\hline 34 weeks & $\begin{array}{c}20.3 \pm \\
0.012 \mathrm{a}\end{array}$ & 999 & 89 & $\begin{array}{c}42 \pm \\
0.034 \mathrm{a}\end{array}$ & $\begin{array}{c}125 \pm \\
0.041 \mathrm{a}\end{array}$ \\
\hline 44 weeks & $\begin{array}{c}20.3 \pm \\
0.009 \mathrm{a}\end{array}$ & 98 & 89 & $\begin{array}{c}43 \pm \\
0.021 \mathrm{~b}\end{array}$ & $\begin{array}{c}130 \pm \\
0.037 \mathrm{~b}\end{array}$ \\
\hline 45 weeks & $\begin{array}{c}20.7 \pm \\
0.016 \mathrm{~b}\end{array}$ & 90 & 80 & $\begin{array}{c}48 \pm \\
0.008 \mathrm{c}\end{array}$ & $\begin{array}{c}141 \pm \\
0.019 \mathrm{c}\end{array}$ \\
\hline 46 weeks & $\begin{array}{c}21.1 \pm \\
0.032 \mathrm{c}\end{array}$ & 85 & 76 & $\begin{array}{c}49 \pm \\
0.015 \mathrm{~d} \\
\end{array}$ & $\begin{array}{c}145 \pm \\
0.011 \mathrm{~d} \\
\end{array}$ \\
\hline
\end{tabular}

Kafr El-Sheikh Vet. Med. J. Vol. 2 No. 2 (2004) 
Mean \pm Standard Error.

* Means which subscript with different small litters(a,b,c...)differ significantly at $(\mathrm{P}<0.05)$.

Table (4): Effect of egg weight on some hatching parameters.

\begin{tabular}{|c|c|c|c|c|c|}
\hline Variables & 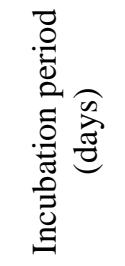 & 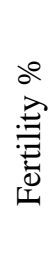 & 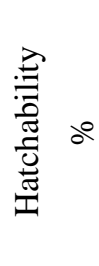 & 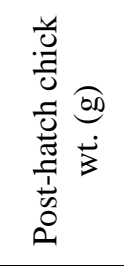 & 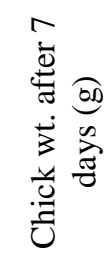 \\
\hline 35 to $45 \mathrm{~g}$ & $\begin{array}{c}20.1 \pm \\
0.018 \mathrm{a}\end{array}$ & 85 & 80 & $\begin{array}{c}30 \pm \\
0.028 \mathrm{a}\end{array}$ & $\begin{array}{c}110 \pm \\
0.017 \mathrm{a}\end{array}$ \\
\hline 46 to $55 \mathrm{~g}$ & $\begin{array}{c}20.7 \pm \\
0.035 \mathrm{~b}\end{array}$ & 90 & 89 & $\begin{array}{c}40 \pm \\
0.039 \mathrm{~b}\end{array}$ & $\begin{array}{c}130 \pm \\
0.011 b\end{array}$ \\
\hline 56 to $65 \mathrm{~g}$ & $\begin{array}{c}21.2 \pm \\
0.021 \mathrm{c}\end{array}$ & 83 & 70 & $\begin{array}{c}50 \pm \\
0.042 \mathrm{c}\end{array}$ & $\begin{array}{c}145 \pm \\
0.009 \mathrm{c}\end{array}$ \\
\hline
\end{tabular}

* Mean \pm Standard Error.

* Means which subscript with different small litters(a,b,c...)differ significantly at $(\mathrm{P}<0.05)$.

\section{REFERENCES}

- Altan, O.; A.Altan;H.Bayraktar, and A.Demircioglu (2002): Effect of short - term storage on hatchability and total incubation period of breeder hatching eggs. Turk- Veterinerlikve- Hayvancilik- Dergisi,26 (3) : 447- 452.

- Bhutia, T. C.; S. C. Majumber; A. K. Samanta, and S. K. Mishra (2002): Studies on incubation, hatching performance and embryonic mortality pattern in different egg weight groups of broiler fowl. J. of Interacademicia, 6: 642 - 645. 
- Elibol,O.;S. D. Peak,and J. Brake (2002): Effect of flock age, length of egg storage and frequency of turning during storage on hatchability of broiler hatching eggs. Poultry Science, 81 (7):945 - 950.

- Elibol, O. and J. Brake (2003): Effect of frequency of turning from three to eleven days of incubation on hatchability of broiler hatching eggs. Poultry Science, 82 (3): 357 - 359.

- Ipek, A., and U. Sahan (2001): Effect of specific gravity and flock age on hatching traits in broiler breeders. TurkVeterinerlikve-Hayvancilik-Dergisi, 25 (6): 817 - 821.

- Kang, X. T.; S. F. Song; M. Li; Y. B. Wang, and J. W. Fu (2002): Effects of egg weight of breeding layer on hatchability and chick growth. China Poultry Science, 24 (15): 10 - 13.

- Kang, B. S.; O.S. Suh; J.C. Na; S.H. Kim; H. K.Kim; B.G Jang; T.H. Kim; S. J. Lee, and J. K. Ha (2002) : The effects of different holding temperatures and storage time during the pre- incubation period on the hatchability of hens eggs in broiler breeders. Korean J.of Poultry Science, 29 (2): 89 - 94.

- Kumar, D.;R. K.Sharma;A. K.Banerjee, and H. Singh (2002): Egg quality characteristics and their impact on fertility and hatchability in indigenous chickens and their crosses. Proceeding of the $7^{\text {th }}$ World Congress on Genetics Applied to Livestock Production, Montpellier, France, pp. 0-3.

- Lapao, C.; L. T. Gama, and M. C. Soares (1999): Effects of broiler breeder age and length of egg storage on albumen characteristics and hatchability. Poultry Science, 78 (5): 640 645. 
- Meijerhof, R. (1995): Influence of storage time, temperature and breeder age on hatchability,World Poultry-Missett, Vol., 11(6): 21-22.

- Mohd Ahmed,A.;S.Balvir;S.S.Chauhan; K. S. Singh, and B. Singh (2000): Effect of breed, egg size and shape on fertility, late embryonic mortality and hatchability.Indian J.of Poultry Science, 35(2):207 - 210.

- Ruiz, J and C. A. Lunam (2002): Effect of pre-incubation storage conditions on hatchability, chick weight at hatch and hatching time in broiler breeders. British poultry Science, 43(3): 374- 383.

- SAS (1985): SAS user's guide: Statistics Version 5 Edition. SAS. Ins. Inc. Cary, NC.

- Tona,K.;F.Bamelis; B. de Ketelaere; V. Bruggeman;V.M. Moraes; J.Buyse;O.Onagbesan;E. Decuypere, and B. de Ketelaere (2003): Effects of egg storage time on spread of hatch, chick quality and chick juvenile growth. Poultry Science, 82(5): $736-74$.

- Tona, K.; R. D. Malheiros; F. Bamelis ; C. Careghi; V. M. Moraes; O. Onagbesan; E. Decuypere, and V. Bruggeman (2003): Effects of storage time on incubating egg gas pressure, thyroid hormones, and corticosterone levels in embryos and on their hatching parameters. Poultry Science, 82 (5): 840 - 845.

- Tullett, S. G. and S. Smith (1983): A note on changes in eggshell porosity with flock age and season during the first breeding cycle of domestic ducks. British Poultry Science, 24 (4): $501-509$. 
- Veterany, L. and J. Jedlicka (2001): The influence of various egg set weight on the weight of chicken embryos and their hatchability. Slovensky-Veterinarsky-Casopis, 26 (3): 160 162.

- Veterany, L., M. Halaj; S. Hluchy, and J. Tedlicka (2001): The influence of egg set weight on chicken hatching. ActaFytotechnica-et-Zootechnica, 4(2): $29-31$.

- Vick, S.V.; J. Brake, and T. J. Walsh (1993): Relationship of incubation humidity and flock age to hatchability of broiler hatching eggs. Poultry Science, 72 (2): 251-258.

تأثثر اختيار بيض أمهات التسمين و فترة التخزين على نسبة الفقس ووزن الكتكوت * طارق محمود موسى بلابل - الصادق خليل يوسف سليم قسم الصحة و الطب الوقائى - كلية الطب البيطرى - جامعة طنطا

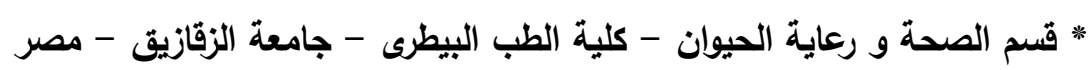
أجريت هذه الدراسة على عدد 800 بيضة مخصبة من أمهات التسمين المرباة على الفرشة

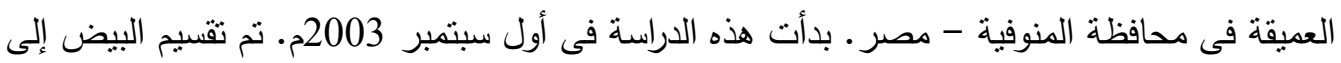

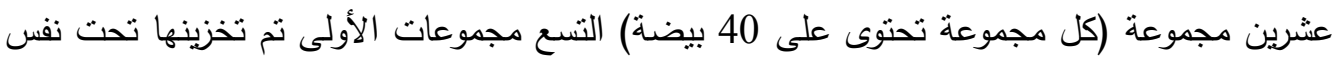
الظروف ولكن لفترات مختلفة (صفر - 3 - 6- 9 - 12 - 15 - 18- 21 - 24 يوم) والمجموعات الأربع التالية من العاشرة إلى الثالثة عشر نم تخزينها لمدة ستة أيام فقط ولكن تختلف في في عدد مرات

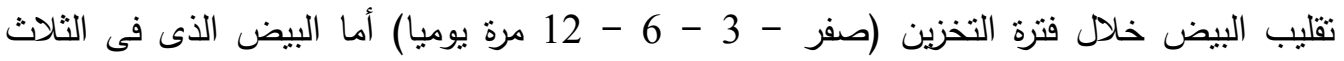
مجموعات التالية بداية من الرابعة عشر إلى السادسة عشر فيختلف فقط في أوزان البيض (ل

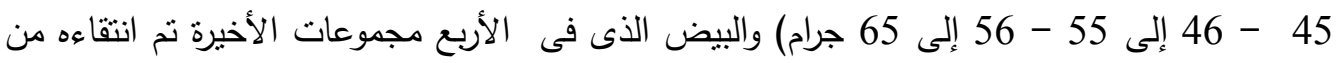

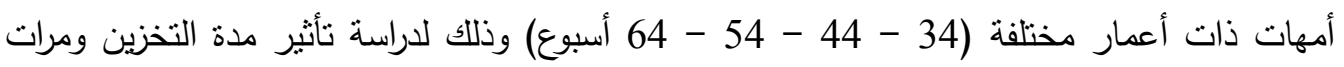

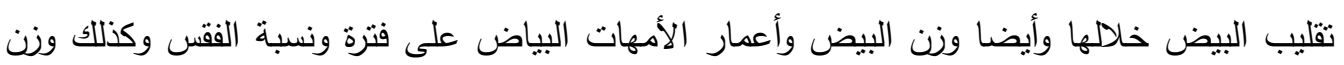

$$
\begin{aligned}
& \text { الكتكوت عند الفقس وأيضا عند عمر سبعة أيام بعد الفقس. } \\
& \text { و أظهرت النتائج الآتى:- } \\
& \text { 1- نقص وزن البيض بزيادة مدة التخزين. }
\end{aligned}
$$


2- زادت فترة الفقس ووزن الكتكوت عند الفقس وبعد سبعة أيام من الفقس بزيادة أعمار أمهات البياض

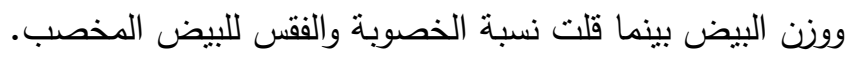

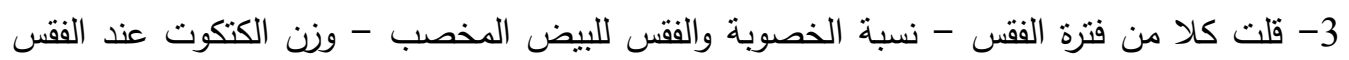

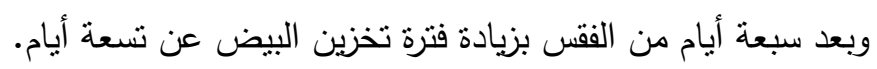

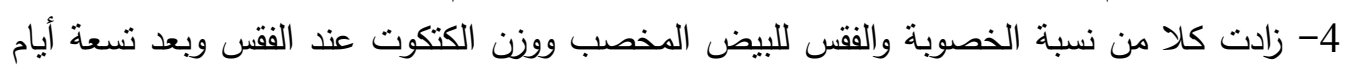

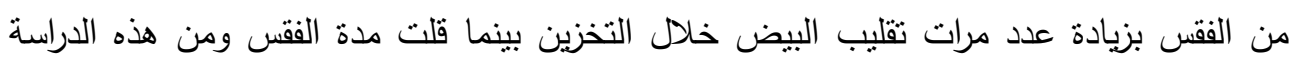

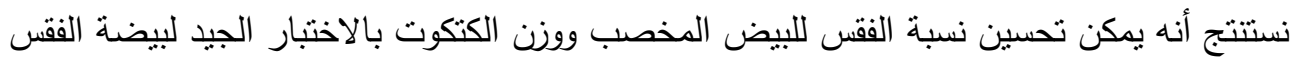

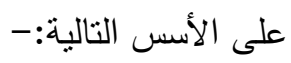

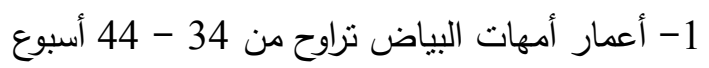

$$
\begin{aligned}
& \text { 2- أوزان البيض تتراوح من } 46 \text { - } 45 \text { - } 55 \text { جرام. } \\
& \text { 3- مدة التخزين قبل الفقس لا تزيد عن } 9 \text { أبيام. } \\
& \text { 4- عدد مرات تقليب البيض أنثاء التخزين لا يقل عن } 3 \text { بن مرة مرات يوميا. }
\end{aligned}
$$

